\title{
THE IMPACT OF INFRASOUNDS GENERATED BY WIND POWER STATIONS ON A HUMAN BEING
}

\author{
Leszek Romański, Jerzy Bieniek, Przemysław Bukowski, Przemysław Kobel \\ Institute of Agricultural Engineering, Wroclaw University of Environmental and Life Sciences \\ *Corresponding author: e-mail: leszek.romanski@up.wroc.pl
}

\begin{tabular}{|c|c|}
\hline ARTICLE INFO & ABSTRACT \\
\hline $\begin{array}{l}\text { Article history: } \\
\text { Received: July } 2015 \\
\text { Received in the revised form: } \\
\text { September } 2015 \\
\text { Accepted: October } 2015\end{array}$ & $\begin{array}{l}\text { In some opinion-forming environments the problem of noise emitted by } \\
\text { wind power stations is very controversial. It is even suggested that they } \\
\text { negatively affect the quality and length of human life. Based on the } \\
\text { review of domestic and foreign publications an analysis of the impact of } \\
\text { the low-frequency noise on a human being was carried out. Wind power }\end{array}$ \\
\hline $\begin{array}{l}\text { Key words: } \\
\text { wind power stations, } \\
\text { noise, } \\
\text { infrasounds }\end{array}$ & $\begin{array}{l}\text { was proved that the level of acoustic pressure with } G \text { weighting does not } \\
\text { exceed the value of } 85 \mathrm{~dB} \text {. The value of the admissible burdensome } \\
\text { noise }(102 \mathrm{~dB}) \text { was exceeded in the bus cabins which were driving with } \\
\text { the speed exceeding } 30 \mathrm{~km} \cdot \mathrm{h}^{-1} \text {. The opinion of the Ministry of Health } \\
\text { confirms the findings. It proves that the present knowledge does not } \\
\text { allow a clear indication of the relation between the wind farms and their } \\
\text { negative impact on the human health. }\end{array}$ \\
\hline
\end{tabular}

\section{Introduction}

Location of wind farms in the neighbourhood of residential buildings often stirs emotions and discussions with more or less substantial arguments provided by followers and opponents. Majority of previously used opponents' arguments such as: "wind stations kill birds and chase out animals"; "the land under the wind power stations is not suitable for cultivation"; "too high level of noises that can be heard" etc., which are far from reality, are rarely used. Today, the main argument posed by some opponents of wind power stations is infrasound and low-frequency noise. Do wind power stations have indeed a negative impact on the human health as some publications suggest? (Nowa Stepnica, 2011).

Wind power stations generate two types of noise: mechanical and aerodynamic. The first one is caused by the operation of devices located in the nacelle of a wind turbine. The level of the acoustic pressure inside the nacelle usually exceeds the value of $110 \mathrm{~dB}$. It is necessary for the persons staying near the wind turbine, that this level is not perceptible inside the nacelle but in a practicable distance therefrom. In Poland and other countries it was assumed that a safe distance of the wind power station from buildings must be at least $600 \mathrm{~m}$; the further the better. As a result of numerous works carried out by constructors of wind power stations, mechanical noise was separated (through the use of acoustic insulations and muting the operation of devices working in the nacelle) to the decisively lower 
level than the standard concerning the noise provisions for (Dz.U. [Journal of Laws] No.178,2004; Dz.U. No.120,2007).

Aerodynamic noise is created at the turbulent air flow and may be of a high and lowfrequency nature. The low-frequency noise (mainly infrasound) is more unfavourable for human health. It is generated during the operation of the wind power station after blades of the turbine rotor go through the area of air with lower pressure, which results from the turbine operation and an uneven distribution of the speed of the flowing stream of winds. Noise spectrum contains infrasound components with levels higher than the levels located in the audible band (Dobrucki and Bogusz, 2011).

Infrasounds are nothing extraordinary. What is more, we may say that it is a natural phenomenon in the surrounding world. They are defined as vibrations of solid bodies and liquids. According to the standard ISO 7196/1995 and ISO 9612/1997, noise or sounds with 1 to $20 \mathrm{~Hz}$ frequency are called infrasounds. The Polish standard PN-Z-01338:2010 uses a wider definition of "infrasound noise'. It says that it is noise, in whose spectrum, components of $2-16 \mathrm{~Hz}$ frequencies (infrasounds) and of audible frequencies to $50 \mathrm{~Hz}$ occur. After this standard was amended in 2010, the range of infrasounds was increased to the range of $1-10 \mathrm{~Hz}$.

\section{The sources of infrasound noise}

Both infrasounds as well as sounds of lower frequency are generated during earthquakes, volcano eruptions, avalanches, during storm with lightnings, tornadoes, they are generated by the aurora polaris, waterfalls, heavy sea and wind. They are generated during the operation of machines and devices (inter alia, they are found in trucks, buses, airplanes during the operation of fans, compressor, hammers and construction vibrators, fridges, air conditioners and wind power stations (table 1). The infrasound noise is generated also during the working liquids dump in plants, thermal and hydra water stations. Even more often infrasounds are generated in passenger cars with loud music on recorded through stereo recorders (the level above $100 \mathrm{~dB}$ ). It must be noted that also purposefully, they are generated by animals in order to communicate to a great distance e.g. by elephants, hippos, giraffes, alligators, whales.

The level of the natural background of infrasounds is $35-40 \mathrm{~dB}$ and for example during storms it exceeds $140 \mathrm{~dB}$.

The infrasound noise is received by sound receptors but also it is felt as pressure in ears, rumble or hum.

\section{Description and properties of infrasounds}

Infrasound waves distribute in matter in the form of circular waves and are weakly absorbed by the centre within which they move. According to table 2 they are characterised by considerable distances, which decrease along with the increase of frequency. Then, they are more absorbed by air. Low-frequency waves - infrasounds can spread in big distances. This ability is used, inter alia, for detection of earthquakes, volcano eruptions or tests with nuclear bombs. At big lengths of waves, their insulation is difficult since acoustic screens are low effective. In the closed objects, they may cause acoustic resonance, which causes 
The impact of infrasounds...

that infrasounds with a proper acoustic level may be a reason for a considerable burden e.g. in submarines, transport fleet or in buildings (Bergluns et al., 1996).

Table 1.

Levels of pressure of the selected natural and anthropogenic sources

\begin{tabular}{|c|c|c|c|}
\hline Natural sources & $\begin{array}{c}\text { Acoustic pressure } \\
\text { level }(\mathrm{dB}) \\
\text { and prevailing } \\
\text { frequency range }(\mathrm{Hz})\end{array}$ & $\begin{array}{l}\text { Anthropogenic } \\
\text { sources }\end{array}$ & $\begin{array}{c}\text { Acoustic pressure } \\
\text { level }(\mathrm{dB}) \\
\text { and prevailing } \\
\text { frequency range }(\mathrm{Hz})\end{array}$ \\
\hline $\begin{array}{l}\text { Volcano eruption, } \\
\text { distance of } 1000 \mathrm{~km}\end{array}$ & $117 \mathrm{~dB}$ at $\mathrm{Hz}<0,01$ & $\begin{array}{l}\text { Start off of a rocket, distance: } \\
\text { - by the launcher } \\
\text { - } 40 \mathrm{~km}\end{array}$ & $\begin{array}{c}188 \mathrm{~dB} \\
77-95 \mathrm{~dB} \\
\text { at }(1-20) \mathrm{Hz}\end{array}$ \\
\hline $\begin{array}{l}\text { Tornado, } \\
\text { distance } 30-800 \mathrm{~km}\end{array}$ & $\begin{array}{l}(67-68) \mathrm{dB} \\
\text { at }(0.02-10) \mathrm{Hz}\end{array}$ & Jet engines & $\begin{array}{c}(85-120) \mathrm{dB} \\
\text { at }(4-31.5) \mathrm{Hz}\end{array}$ \\
\hline $\begin{array}{l}\text { Snow avalanche, } \\
\text { distance } 100 \mathrm{~km}\end{array}$ & $\begin{array}{l}(60-68) \mathrm{dB} \\
\text { at }(0.05-2) \mathrm{Hz}\end{array}$ & Propeller planes, helicopters & $\begin{array}{l}(80-115) \mathrm{dB} \\
\text { at }(1-20) \mathrm{Hz}\end{array}$ \\
\hline $\begin{array}{l}\text { Wind } \\
\text { speed } 25 \mathrm{~km} \cdot \mathrm{h}^{-1} \\
\text { speed } 100 \mathrm{~km} \cdot \mathrm{h}^{-1}\end{array}$ & $\begin{array}{l}110 \mathrm{~dB} \\
135 \mathrm{~dB} \\
\text { at } \mathrm{Hz}<1\end{array}$ & Fans, air blowers & $\begin{array}{l}(90-108) \mathrm{dB} \\
\text { at }(2-8) \mathrm{Hz}\end{array}$ \\
\hline Waterfalls & $\begin{array}{l}(95-100) \mathrm{dB} \\
\text { at }(2-12) \mathrm{Hz}\end{array}$ & Wind turbines & $\begin{array}{l}(90-115) \mathrm{dB} \\
\text { at }(2-12) \mathrm{Hz}\end{array}$ \\
\hline Lightning strike & $\begin{array}{l}(90-100) \mathrm{dB} \\
\text { at }(1-10) \mathrm{Hz}\end{array}$ & Bus or truck cabin & $\begin{array}{c}(97-100) \mathrm{dB}(\mathrm{G}) \\
\text { at }(1-20) \mathrm{Hz}\end{array}$ \\
\hline Ear cleaning & $\begin{array}{l}185 \mathrm{~dB} \\
\text { at }(3-5) \mathrm{Hz}\end{array}$ & Wind power stations & $\begin{array}{c}(95-110) \mathrm{dB} \\
\text { at }(1-5) \mathrm{Hz}\end{array}$ \\
\hline
\end{tabular}

Table 2 .

Relation of the length of infrasound waves spreading in air to frequency

\begin{tabular}{lc}
\hline Frequency & $\begin{array}{c}\text { Length of waves } \\
(\mathrm{m})\end{array}$ \\
$\mathrm{Hz}$ & 3,400 \\
0.1 & 340 \\
1 & 34 \\
10 & 3.4 \\
100 & 0.34 \\
1000 & 0.034 \\
10,000 & \multicolumn{2}{c}{ Source: ISO 7196: 1995}
\end{tabular}

\section{Impact of infrasounds on the human body}

With regard to infrasounds, the hearing perception determined as "hearing" does not exist but these sounds are perceived by the organism by a specific hearing way (Pawlas, 2009) and through vibration receptors. The border between "hearing" and "sensing" is almost invisible and depends greatly on the level of acoustic pressure as well as on the predisposition of a particular specimen. One may wonder where the border between hearing, sensing 
and silence is. The hearing and sensing thresholds are presented in table 3 and were arranged so that over $50 \%$ of the tested people does not hear the below values or does not sense infrasounds.

Table 3.

Average values of hearing and sensing thresholds for the range of 4-20 Hz

\begin{tabular}{lcccccc}
\hline $\begin{array}{l}\text { The investigated } \\
\text { thresholds }\end{array}$ & $4 \mathrm{~Hz}$ & $8 \mathrm{~Hz}$ & $10 \mathrm{~Hz}$ & $12.5 \mathrm{~Hz}$ & $16 \mathrm{~Hz}$ & $20 \mathrm{~Hz}$ \\
\cline { 2 - 6 } & 111 & 103 & 95 & 87 & 79 & 71 \\
\hline $\begin{array}{l}\text { Hearing threshold acc. to } \\
\text { DIN 45680:1997 }\end{array}$ & 108 & 100 & 97 & 92 & 88 & 79 \\
\hline $\begin{array}{l}\text { Hearing threshold acc. to } \\
\text { (Watanabe 1990) }\end{array}$ & 105 & 100 & 92 & 84 & 76 & 68.5 \\
\hline $\begin{array}{l}\text { Perception threshold } \\
\begin{array}{l}\text { According to DIN } \\
\text { 45680:2011 }\end{array}\end{array}$ & \multicolumn{5}{c}{ Source: DIN 45680: 1997; DIN 45680:2011; Watanabe and Moller,1990 }
\end{tabular}

Simultaneously, the table shows that the lower frequency is, the higher the acoustic pressure level must be - louder sound that a man can hear or perceive. For example at $4 \mathrm{~Hz}$ frequency the acoustic pressure level must reach $105 \mathrm{~dB}$ and at $20 \mathrm{~Hz}$ frequency only ca. $68 \mathrm{~dB}$.

In order to assess the acoustic quality of the surrounding environment and in order to assess the human exposure to noise, corrective curves were introduced, which approximate the human ear sensitivity to the scale of energy carried out by sound. Corrective curves are marked with letters A, C and G. Figure 1 presents the course of sound frequency weighting curves. A scale is commonly applied. It reflects quite well the ear sensitivity for low frequencies.

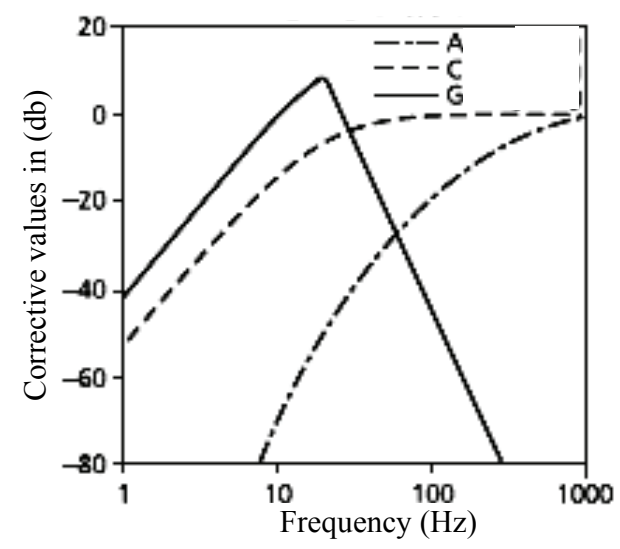

Figure 1. Frequency weighting curves A, G and C (acc. to PN-ISO 7196:2002 and Renewable Energy (World.Com, 2015) 
The impact of infrasounds...

The sound volume in this scale is denoted as $\mathrm{dB}(\mathrm{A})$. The A frequency characteristic has a drawback because it does not estimate expositions from the infrasound range and low frequencies because it reduces them (high negative values). On the other hand, frequency characteristic $\mathrm{G}$ eliminates the low frequencies range and omits the audible range promoting the same the infrasounds range. Type $\mathrm{C}$ characteristic according to figure 1 seems to be a compromise between two mentioned characteristics in case the assessed noise is composed of audible sounds, low-frequency sounds and infrasounds (Pawlas et al., 2013).

One should be aware that except for Denmark, in Europe there are no separate regulations for low frequency sounds and infrasounds in the human living environment and the admissible noise level is determined with the use of A frequency characteristic. Also, despite some reservations, WHO recognizes this manner of defining the noise (Berglund et al., 1999).

Also in Poland, regardless the frequency composition, the admissible level of noise in the human living environment is determined with admissible values of the A sound level; e.g. $40 \mathrm{~dB}$ at night (Journal of Laws No. 178, 2004 and Journal of Laws. No. 120, 2007).

On the other hand, for assessment of the infrasound noise at the workplace, one may use a burden criterion (not harmfulness criterion) defined in the Polish standard (PN-Z-01338: 2010) and for all employees this value is $102 \mathrm{~dB} \mathrm{G}$ and at the conceptual work stands it is $86 \mathrm{~dB}$ G.

\section{Noise generated by wind power stations}

Figure 2 presents the noise spectra of the wind power station Vestas V80 located at the edge of the wind farm near Zagorz. The closest wind power station was located $800 \mathrm{~m}$ from buildings. Its nominal power is $2 \mathrm{MW}$ (at the moment of measurement it is approx. $0.6 \mathrm{MW})$. Measuring devices were mounted on the downwind side at the height of $1 \mathrm{~m}$ and in the distance of $200 \mathrm{~m}$ from the tower. The wind speed was $8 \mathrm{~m} \cdot \mathrm{s}^{-1}$ (Golec et al., 2006). The presented nomogram shows that the infrasound noise did not exceed the level of $68 \mathrm{~dB}$ and the low-frequency noise slightly exceeded the value of $60 \mathrm{~dB}$. It should be mentioned that very similar values for this type of power stations were obtained also by other researchers (Rogers et al., 2006).

The noise spectrum of the wind power stations with the power of $1.5 \mathrm{MW}$ was presented in figure 3. Simultaneously, the level of reference, that is, the acoustic background level was marked with red. It is characteristic that within the range of infrasounds, these levels differed slightly. Other authors (Jakobsen, 2005) examining Enercom E40 wind power station claim that similar values of the noise level occur only within the range of $1-4 \mathrm{~Hz}$ and within the range to the value of $30 \mathrm{~Hz}$ the noise level generated by a turbine is higher by $10 \mathrm{~Hz}$ than the acoustic background. Dobrucki and Bogusz (2011) recorded slightly lower differences of the noise level between the acoustic background and infrasounds generated by Nordex N-80 wind power station with the nominal power of $2.5 \mathrm{MW}$.

They reported $4-5 \mathrm{~Hz}$ differences due to constant recording of the sound level at the infra level during the operation of the wind power station and immediately after it stopped, namely at 1:56. p.m. Another start was recorder at 2:17 p.m. (figure 4). 


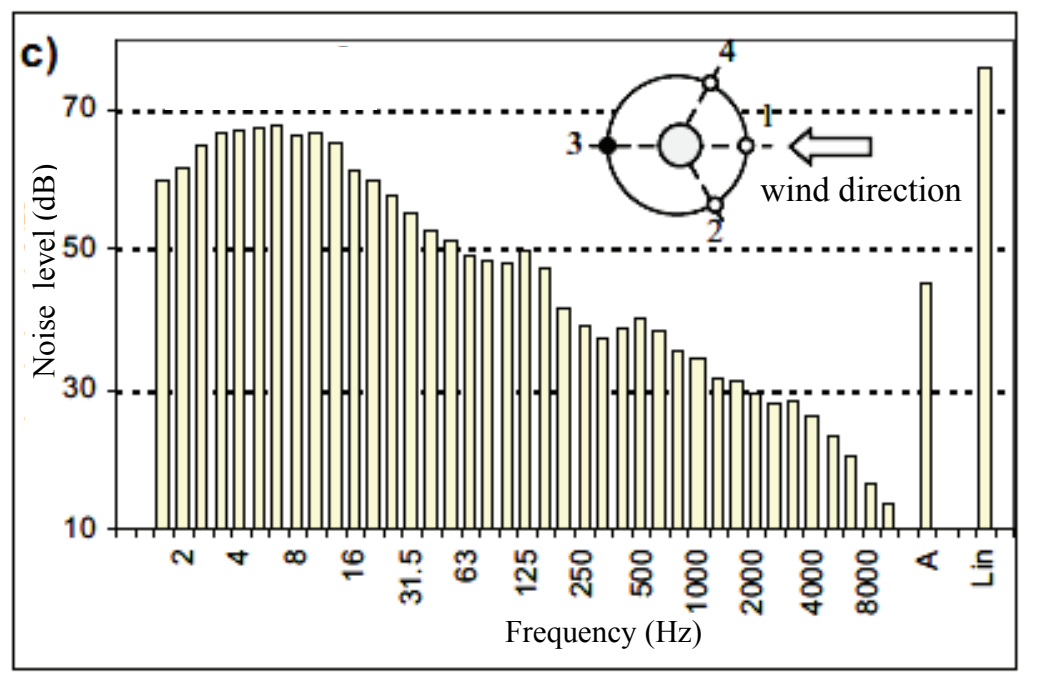

Figure 2. Averaged spectra of noise of V80 wind power station (Golec et al., 2006)

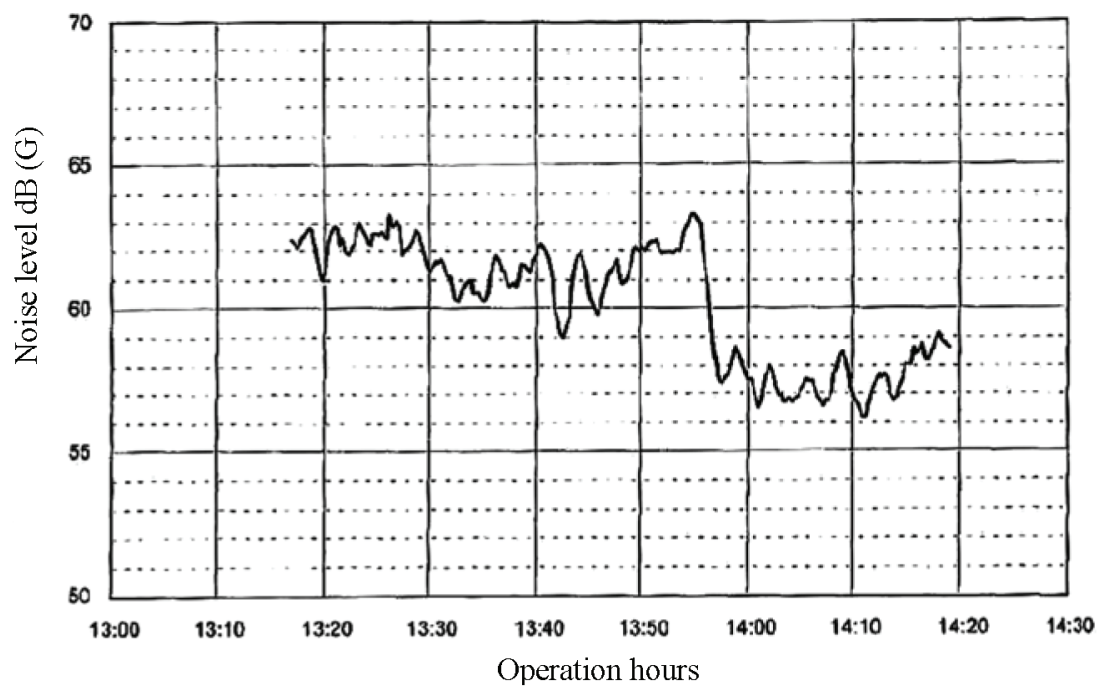

Figure 3. The sound level weighted with the curve of Nordex N-80 wind power station. Distance of the measurement point $200 \mathrm{~m}$ from the tower. Stopping the wind power station at 13:56 p.m. (Dobrucki and Bogusz, 2011) 
The impact of infrasounds...

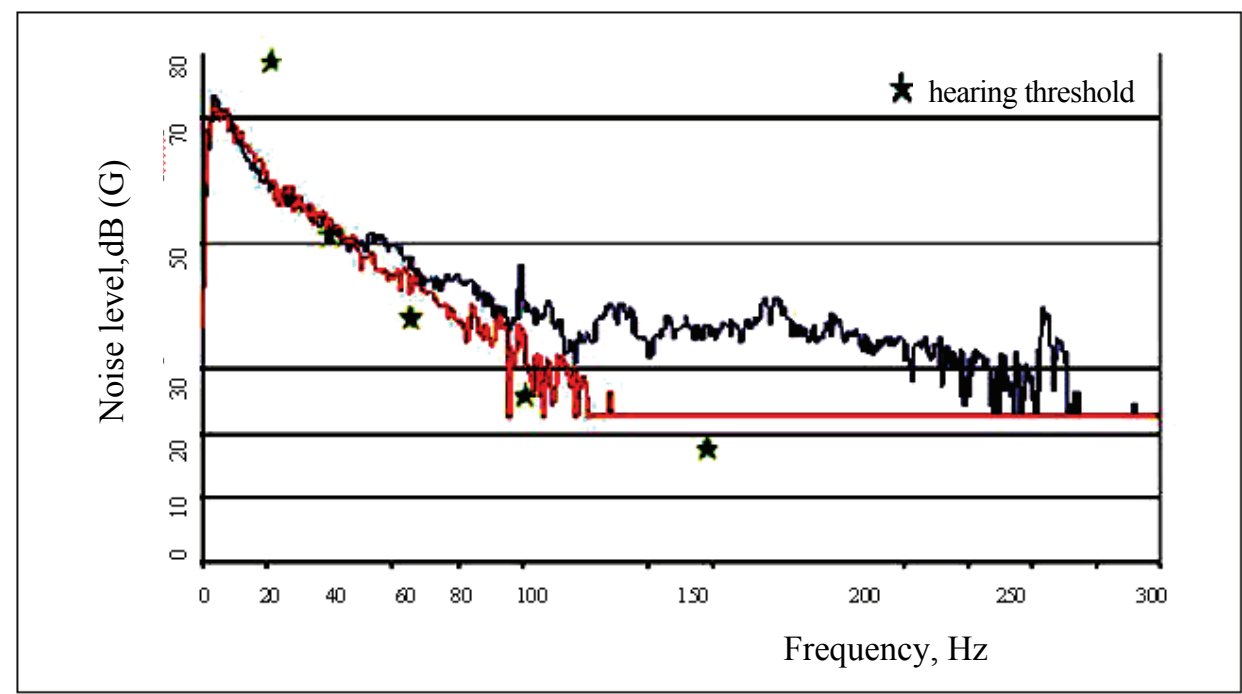

Figure 4. The noise spectrum of the wind power station with the power of $1.5 \mathrm{MW}$. Natural background was marked with red. Distance of the measurement point from the tower - 65 m (according to Leventhall, 2006)

The enclosed table 4 shows that the average speed of wind at which the wind turbine operated was approx. $8 \mathrm{~m} \cdot \mathrm{s}^{-1}$.

Table 4.

Average levels of $G$ sound of Nordeks $N 80$ wind turbine in the distance of $200 \mathrm{~m}$ after removal of the acoustic background impact

\begin{tabular}{lcccccccc}
\hline $\begin{array}{l}\text { Speed } \\
\left(\mathrm{m} \cdot \mathrm{s}^{-1}\right)\end{array}$ & 5 & 6 & 7 & 8 & 9 & 10 & 11 & 12 \\
\hline $\begin{array}{l}\text { Sound level } \\
(\mathrm{dB} \mathrm{G})\end{array}$ & 58 & 59 & 60 & 62 & 62 & 63 & 64 & 65 \\
\hline
\end{tabular}

The noise level emitted by numerous wind power stations grouped on one area - on a farm is certainly higher than the noise emitted by a single power station. Differences can be noticed after the analysis of figure 4 and 5 . Figure 5 presents the results of 15-hours recording of acoustic pressure levels with the use of the weighting curve $G$, of the wind farm consisting of 12 wind power stations Nordex N-80 with the nominal power of $2.5 \mathrm{MW}$ each (Hepburn and Edworthy, 2005). The measurement point was in the distance of $200 \mathrm{~m}$ from the wind power station tower. 


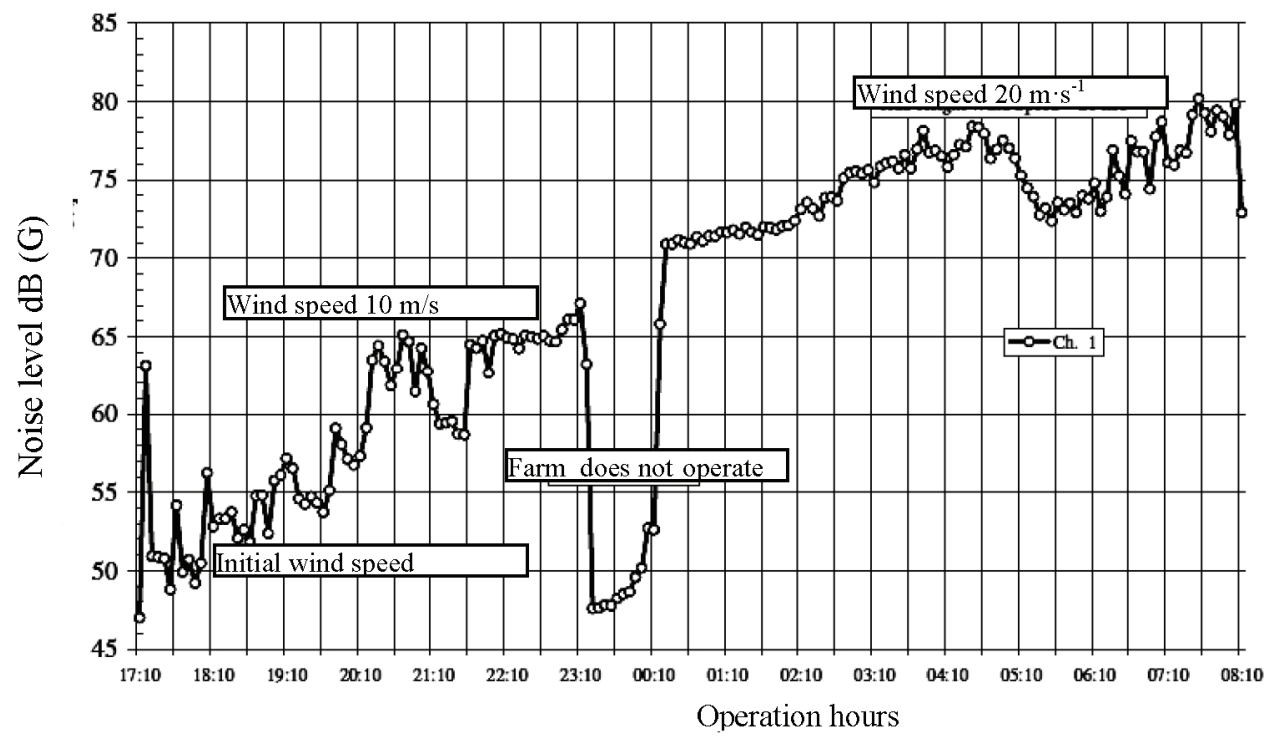

Figure 5. Course of the acoustic pressure variability with $G$ weighting during operation of the wind farm (Hepburn and Edworthy, 2005)

At the speed of $10 \mathrm{~m} \cdot \mathrm{s}^{-1}$ the level of infrasound noise emitted by the wind farm was approximately $66 \mathrm{~dB} \mathrm{G}$, and at the wind speed of $20 \mathrm{~m} \cdot \mathrm{s}^{-1}$ (very rare) approx. $80 \mathrm{~dB}$ G. At the decrease of the wind speed below the initial speed $\left(3 \mathrm{~m} \cdot \mathrm{s}^{-1}\right)$, wind power stations did not work and only infrasound noise included in the acoustic background was recorded and it was approx. $47 \mathrm{~dB}$ G. This value is by $10 \mathrm{~dB}$ lower than the one presented in figure 10 . The reason for differences may result from another surrounding of the investigated objects or from correctness of the measurements, which is less probable. However, in each case, the obtained values are lower than the hearing and perception thresholds for the range of 4-20 Hz (DIN 45680:1997).

The list of the level of infrasound and low-frequency noise of a wind farm as the function of frequency was presented in figure 6 . The measurements were carried out according to the standard IEC 61400-11. For absolute correctness of the obtained results, a microphone was secured with an additional anti-wind shell with $650 \mathrm{~mm}$ diameter (Hepburn $\mathrm{H}$ and Edworthy, 2005). Curve 1 defines the level of noise near the wind power station when it does not operate (acoustic background), curve 2 is noise at a low wind speed (approx. $\left.6 \mathrm{~m} \cdot \mathrm{s}^{-1}\right)$. Curve 3 - presents the noise level at a very high wind speed $\left(20 \mathrm{~m} \cdot \mathrm{s}^{-1}\right)$. The level of sound weighted with curve $\mathrm{G}$ is reflected by curve 4 . Curve 7 (acc. to ISO 226) presents the hearing thresholds within the range of audible frequencies and curve 5 presents them within the range of infrasounds. Low-frequency values for the night time according to recommendations of the Department for Environment, Food and Rural Affairs DEFRA are presented by curve 6 . 
The impact of infrasounds...

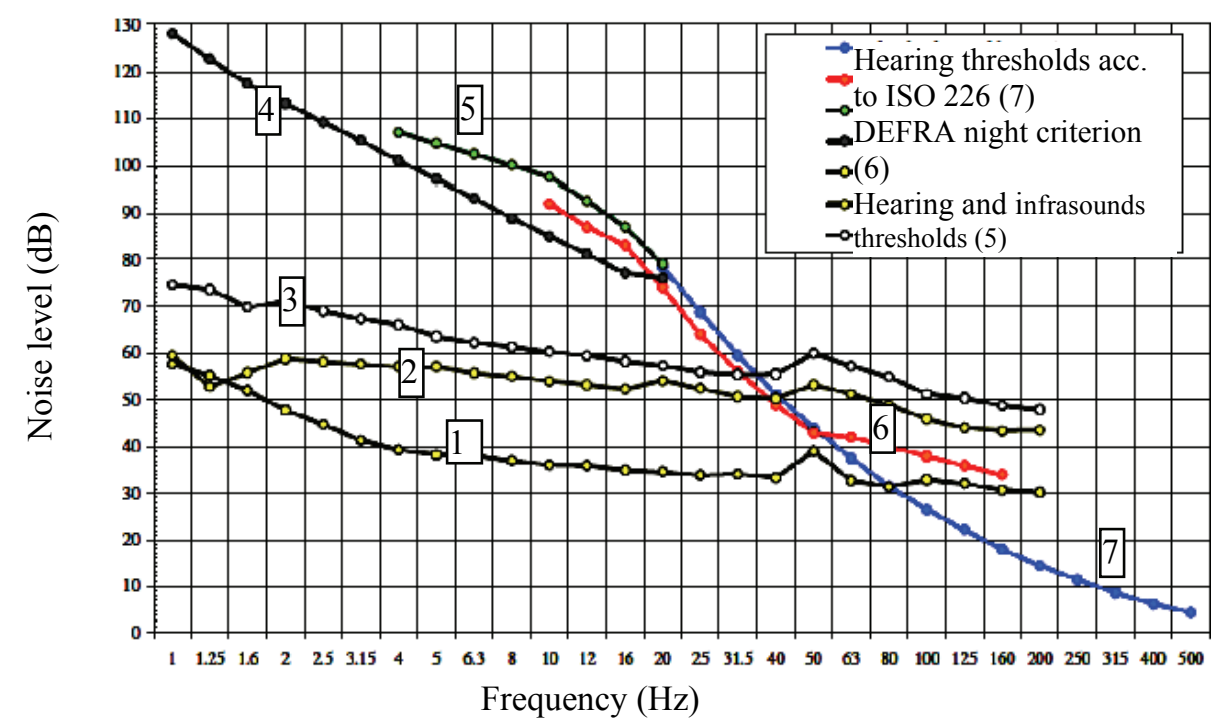

Figure 6. Infrasound and low-frequency noise of a wind farm (Hepburn and Edworthy, 2005)

Analysis of figure 6 shows that in comparison to the acoustic background (wind power stations do not operate) the level of infrasound noise emitted by wind power stations at low wind speed within frequencies of 3-20 Hz increases by $16-19 \mathrm{~Hz}$. For high speed of $20 \mathrm{~m} \cdot \mathrm{s}^{-1}$ the level of noise increases by approx. $25 \mathrm{~dB}$.

Results of research of modern wind power stations, presented in figures 4-6 do not prove that the level of infrasounds exceeds the threshold values recognized presently as harmful for the human health.

\section{Examples of the noise level generated by other sources than wind power stations}

Extensive research of the infrasound noise at the bus and truck drivers' workplace was carried out in the Central Institute of Work Protection (Kaczmarska et al., 2007). Vehicles were moving on the asphalt surface of Modlin airport and on Radzymin ringroad. The noise level did not exceed then the value of $45 \mathrm{~dB}$. Exemplary results during testing of the city bus were presented in figure 7. As expected, the noise level was increasing along with the driving speed increase. It was noticed that shortly after the bus exceeded $30 \mathrm{~km} \cdot \mathrm{h}^{-1}$ the value of the equivalent sound level $\mathrm{G}$ exceeded the admissible value (burdensome level) of $102 \mathrm{~dB}$ G. The sound level of A type increased at the speed of $30-100 \mathrm{~km} \cdot \mathrm{h}^{-1}$ from the value of $58 \mathrm{~dB}$ to $73 \mathrm{~dB}$. 


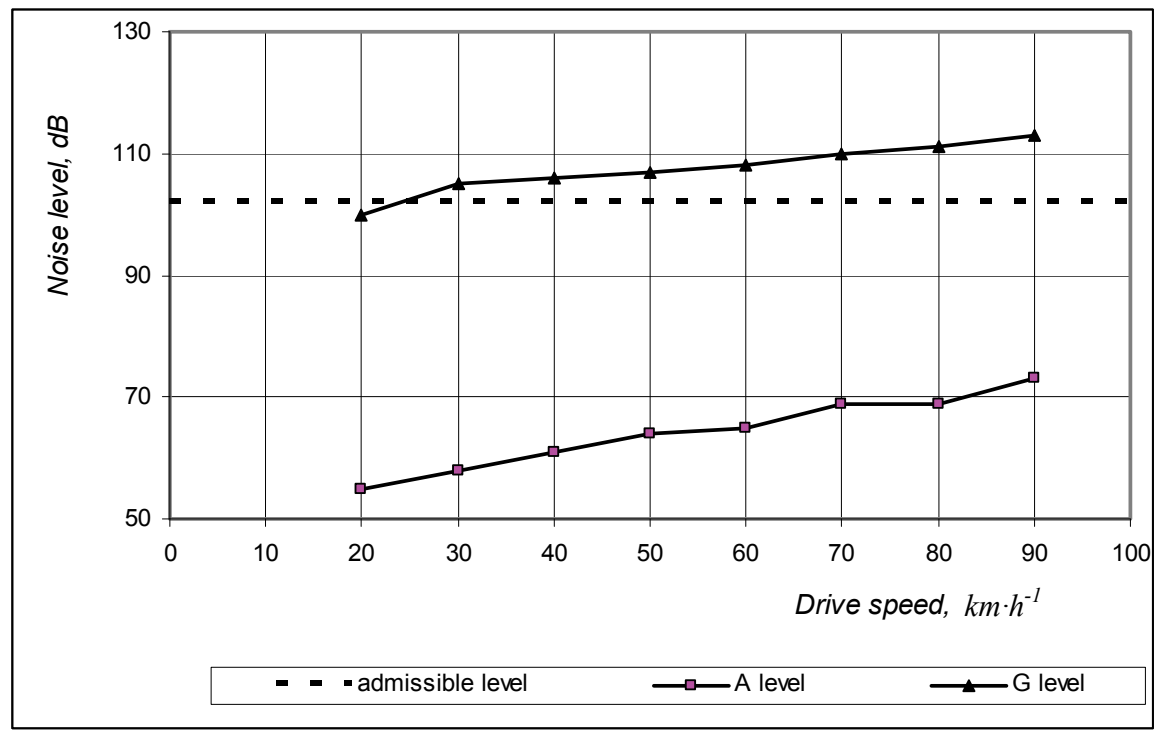

Figure 7. A and G sounds level in the driver's cabin as the function of speed of the bus (Kaczmarska et al., 2007)

Table 6 contains the values of the equivalent level of $\mathrm{G}$ sounds in passenger cars and in the office. According to the table, the passenger car ride on the road with an uneven surface generates infrasound noise which is perceivable in the driver's cabin and exceeds the admissible value of $102 \mathrm{~dB} \mathrm{G}$; similarly, with the ride on an even surface of the road but with the speed above $100 \mathrm{~km} \cdot \mathrm{h}^{-1}$. On the background of those two examples, the wind turbine seems to be considerably favourable.

Table 6.

The level of the acoustic pressure in $d B G$ for sources with spectra with the frequency of 4$30 \mathrm{~Hz}$

\begin{tabular}{|c|c|}
\hline Source and place of the registered noise & $\begin{array}{l}\text { The level of infrasound noise } \\
\qquad(\mathrm{dB} \mathrm{G})\end{array}$ \\
\hline $\begin{array}{l}\text { Inside of the passenger car. Drive with the speed of } 30 \mathrm{~km} \cdot \mathrm{h}^{-1} \text { on the } \\
\text { basaltic brick }\end{array}$ & 115.7 \\
\hline Inside of the passenger car. Drive with the speed of $100 \mathrm{~km} \cdot \mathrm{h}^{-1}$ & 102.7 \\
\hline Office with the area of $60 \mathrm{~m}^{2}$, work of computers and air conditioners & 73.6 \\
\hline Wind power station $0.5 \mathrm{MW}$. Distance of $200 \mathrm{~m}$ from the tower & 63.9 \\
\hline
\end{tabular}

\section{Conclusion}

The problem of the impact of infrasounds generated by the wind power stations on human is perceived by many environments as extremely different. For instance, analyses and documentations prepared by the Chancellery of the Senate of the Republic of Poland prove 
The impact of infrasounds...

that the "number of research and publications is sufficient enough to not question the harmful and burdensome impact of infrasound generated by wind turbines (The Chancellery of the Senate, 2011). This and numerous other publications emphasise that the acoustic pressure level exceeding the value of $140-150 \mathrm{~dB}$ then infrasounds may cause harmful changes in the organism".

In fact, even within so small distance from the wind power station as $200 \mathrm{~m}$ (to remind in Poland this distance is assumed to be not lower than $600 \mathrm{~m}$ ) the noise level is at least half less. Department of the Public Health of the Ministry of Health also notices the above and states "all research show that the noise emitted by wind power stations does not exceed the acoustic pressure level of $85 \mathrm{~dB}$ and the present knowledge does not allow to unanimously indicate the relation between the wind farms and their negative impact on human health (Ministry of Health, 2011 and Ministry of Health, 2013). Researchers from the Institute of Work and Environmental Health concluded similarly but explicitly showed that the lowfrequency noise does not cause the vibro-acoustic disease (Pawlas et al., 2014).

\section{References}

Betke, K., Remmers, H. (1998). Messung und Bewertung von tieffequentem Schall. DAGA.

Berglund, B., Hassman, P., Job, R. (1996). Sources and effects of low-frequency noise. Journal of the Acoustical Society of America, 99(5), 2985-3002.

Berglund, B., Lindvall, T. (1999). Gueidelines for community Noise. WHO.

Cieślikowski, B., Pedryc, N. (2010). Propagacja hałasu w procesie transportu pneumatycznego cukru z wykorzystaniem sprężarki ciągnika siodłowego. Inżynieria Rolnicza, 1(21), 15-20.

DIN 45680:1997-03. Titel (deutsch): Messung und Bewertung tieffrequenter Geräuschimmissionen in der Nachbarschaft.

DIN 45680: 2011-08: Messung und Beurteilung tieffrequenter Geräuschimmissionen.

Dobrucki, A., Bogusz, B. (2011). Oddziaływanie infradźwięków generowanych przez turbiny wiatrowe na zdrowie czlowieka. Raport Nr I-28/11/S-070. Politechnika Wrocławska

Golec, M., Golec, Z., Cempel, R. (2006). Hałas turbiny wiatrowej Vestas V80 podczas eksploatacji. Diagnostyka, 1(37), 115-120.

Dz.U. Nr.178.2004. Rozporzadzenie Ministra Środowiska w sprawie dopuszczalnych poziomów hałasu w środowisku.

Dz.U. Nr.120.2007. Rozporządzenie Ministra Środowiska w sprawie dopuszczalnych poziomów hałasu w środowisku.

Hepburn, H., Edworthy, J. (2005). Observations from Castle River Wind Farm. Canadian Wind Energy Conference. Toronto.

ISO 7196:1995. Acoustics- Frecuency- weighting charakterystic for infrasound measurements.

Jakobsen, J. (2005). Infrasound Emission from Wind Turbines. Journal of low frequency noise, vibration and active control, 24(3), 45-55.

Kaczmarska, A., Augustyńska, D. (2007). Hałas infradźwiękowy na stanowiskach pracy kierowców w warunkach eksperymentalnych. Bezpieczeństwo Pracy-nauka i praktyka, 7-8, 12-15.

Kancelaria Senatu. (2011). Energetyka wiatrowa a społeczności lokalne. Obtained from: www.senat.gov.pl/gfx/senat/pl/senatopracowania/16/plik/ot-600.pdf

Lebiedowska, L., Lebiedowski, M. (2012). Inra- i inne dzwięki emitowane przez turbiny wiatrowe oraz problemy z ich lokalizacją. Obtained from: www. stopwiatrakom.eu/pliki/halas_ wiatraków.pdf.

Leventhall, G. (2006). Infrasound from wind turbines - Fact, Fiction or deception. Canadian Acoustics, Vol.34, 2, 29-36. 
Markiewicz-Górka, J., Kawalec, A., Pawlas, N. (2014). Porównanie efektów zdrowotnych wywołanych zawodową ekspozycją na hałas niskoczęstotliwościowy i hałas słyszalny. Environmental Medicine. Vol. 17, 1, 41-51.

Ministerstwo Zdrowia. (2011). Opinia Departamentu Zdrowia Publicznego Ministerstwa Zdrowia.

Ministerstwo Zdrowia. (2013). Opinia Departamentu Zdrowia Publicznego Ministerstwa Zdrowia na temat lokalizacji elektrowni wiatrowych. Obtained from: www.kochamymazury.pl/pdf/ODP MZ BL.pdf.

Nowa Stepnica. (2011). Obtained from: http://nowa-stepnica.x25.p1/2011/11/18/cicha-smiercwiatraki-zabijaja-ludzi.

Pawlas, K. (2009). Wpływ infradźwięków i hałasu o niskich częstotliwościach na człowieka. Podstawy i Metody Oceny Środowiska Pracy, 2(60), 27-64.

Pawlas, K., Pawlas, N., Boro, M., Zachara, J.(2013). Przegląd kryteriów oceny infradźwięków i hałasu niskoczęstotliwościowego w środowisku zawodowym. Environmental Medicine. Vol. 12, 1, 82-89.

Pawlas, K., Boroń, M., Zachara, J., Szłapa, P., Kozłowska, A., Będkowska, K., Januszewska, L. (2014). Porównanie efektów zdrowotnych wywołanych zawodowa ekspozycja na hałas niskoczęstotliwościowy i hałas słyszalny. Environmental Medicine. Vol. 17, 1, 41-51.

PN-Z-01338: 2010. Akustyka. Pomiar i ocena hałasu infradźwiękowego na stanowisku pracy.

PN-ISO 7196:2002 Akustyka. Charakterystyka częstotliwościowa filtru do pomiaru infradźwięków.

Renewable Energy.World.Com. 2015. Wind Turbine Sound Measurements. Obtained from: www.oto.2.wustl.edu/cochlea/wt.html.

Rogers, A, Maxwell, J, Wright, S. (2006). Wind Turbine Acoustic Noise. Renewable Energy Reasearch Laboratory, 1, 26.

Watanabe, T., Moller, H. (1990). Low frequency hearing threshold in pressure and in free field. Journal of Low Frequency Noise and Vibration 9(3), 106-115.

\section{WPLYW INFRADŹWIĘKÓW GENEROWANYCH PRZEZ ELEKTROWNIE WIATROWE NA CZLOWIEKA}

Streszczenie. W niektórych środowiskach opiniotwórczych wiele kontrowersji wzbudza problem hałasu jaki emitują elektrownie wiatrowe. Sugeruje się nawet, że mają one bardzo negatywny wpływ na jakość i długość życia człowieka. Na podstawie przeglądu publikacji krajowych i zagranicznych wykonano analizę wpływu hałasu niskoczęstotliwościowego na człowieka. Źródłem hałasu były elektrownie wiatrowe pracujące w skupiskach (farmy). Wykazano, że poziom ciśnienia akustycznego $\mathrm{z}$ ważeniem $\mathrm{G}$ nie przekraczał wartości $85 \mathrm{~dB}$. Wartość dopuszczalnego poziomu uciążliwego (102 dB) przekraczana była natomiast $\mathrm{w}$ kabinach autobusów poruszających się z prędkością przekraczającą $30 \mathrm{~km} \cdot \mathrm{h}^{-1}$. Potwierdzeniem poczynionych ustaleń jest opinia Ministerstwa Zdrowia z której wynika, że obecna wiedza nie pozwala na jednoznaczne wskazanie związku pomiędzy farmami wiatrowymi i ich negatywnym wpływem na zdrowie człowieka.

Słowa kluczowe: elektrownie wiatrowe, hałas, infradźwięki 